DOI: https://doi.org/10.32836/2521-666X/2019-65-28

УДК 336.77:332.2:63

\author{
Мельник Л.В. \\ кандидат економічних наук, доцент, \\ Національний університет водного господарства \\ та природокористування
}

\title{
Melnyk Leonid
}

National University of Water Management and Environmental Engineering

\section{ОЦНКА СТАНУ ДЕРЖАВНОГО РЕГУЛЮВАННЯ РЕСУРСНОГО ПОТЕНЦІАЛУ АГРАРНОЇ СФЕРИ}

\author{
ASSESSMENT OF THE STATE REGULATION \\ OF RESOURCE POTENTIAL OF AGRARIAN SECTOR
}

Виокремлено основні напрями діяльності держави щодо забезпечення комплексного розвитку аграрної галузі. Проведено оиінку стану держсавної фінансової підтримки розвитку аграрного сектору. Систематизовано основні державні програми підтримки аграрних підприємств. Проаналізовано динаміку обсягів та структуру фінансування державних програм підтримки сільськогосподарських підприємств на безповоротній та поворотній основі. Проведено оцінку рівня виконання бюджетного фінансування програм розвитку галузі. Виокремлено причини недовикористання бюджетних коштів. Наголошено на наявності значної потреби суб 'єктів аграрного підприємнищтва у бюджетній підтримиі галузі шляхом реалізації заходів прямого та непрямого державного регулювання. Обтрунтовано необхідність становлення в Україні повноцінної системи агроінвестування.

Ключові слова: іпотечне кредитування, фінансова підтримка, регулювання, аграрна сфера, ресурсний потенціал. 
Выделены основные направления деятельности государства по обеспечению комплексного развития аграрной отрасли. Проведена оценка состояния государственной финансовой поддержски развития аграрного сектора. Систематизированы основные государственные программы поддержки аграрных предприятий. Проанализирована динамика объемов и структура финансирования государственных программ поддержки сельскохозяйственных предприятий на безвозвратной и возвратной основах. Проведена оценка уровня бюджетного финансирования программ развития отрасли. Выделены причины недоиспользования бюджетных средств. Сделаны выводы о наличии значительной потребности субъектов аграрного предпринимательства в бюджетной поддержке отрасли путем реализации мер прямого и косвенного государственного регулирования. Обоснована необходимость становления в Украине полноценной системы агроинвестирования.

Ключевые слова: ипотечное кредитование, финансовая поддержка, регулирование, аграрная сфера, ресурсный потенциал.

Constructive changes in agriculture require significant financial inflows, which can be achieved through a mortgage lending system. In turn, the effective functioning of the mortgage lending system is not possible without state regulation and support, taking into account the features and capabilities of agricultural production. The purpose of the study is to analyze the state of financial support to the agricultural sector and to identify areas for improvement of state regulation of financial support to the industry through the use of the potential of mortgage lending. The article outlines the main directions of the state's activity in ensuring the complex development of the agricultural sector. The state of financial support for the development of the agrarian sector from the state side was evaluated. The main state programs for support of agricultural enterprises have been systematized. The dynamics of volumes and structure of financing of state programs of support of agricultural enterprises on irreversible and rotary basis are analyzed. The level of implementation of budget financing of the industry development programs has been evaluated. The reasons for under-utilization of budget funds are highlighted. It is concluded that there is a significant need for agrarian entrepreneurs in the budget support of the industry through the implementation of measures of direct and indirect state regulation. The necessity of establishment of a full-fledged agro-investment system in Ukraine by promoting the development of mortgage lending infrastructure of agrarian business entities, using organizational methods of state regulation, has been justified: creation of a system of specialized mortgage credit institutions, including a state mortgage institution; implementation of the system of state registration of rights to real estate and mortgages, state land cadastre; improvement of the system of notarial services, appraisal, insurance, court activity; formation of credit bureaus, etc. The necessity of introduction of the land market for effective functioning of the land-mortgage lending to the agrarian industry is emphasized.

Key words: mortgage lending, financial support, regulation, agrarian sphere, resource potential.

Постановка проблеми. Розвиток аграрного виробництва в сучасних умовах виступає важливим чинником успішного розвитку економіки України загалом. Забезпечення сприятливих умов для існування аграрного бізнесу та підтримання його конкурентоспроможності на належному рівні неможливе без участі держави як суб'єкта регулювання та учасника економічних відносин. Конструктивні зміни в сільському господарстві потребують суттєвих фінансових вливань, що може бути досягнуто через систему іпотечного кредитування. А тому дослідження проблем державного регулювання та підтримки використання ресурсного потенціалу іпотечного кредитування з урахуванням особливостей та можливостей сільськогосподарського виробництва $є$ надзвичайно актуальним питанням сьогодення.

Аналіз останніх досліджень і публікацій. Проблеми функціонування системи іпотечного кредитування досліджувались у наукових працях таких учених, як О. Гривківська, М. Дем'яненко, О. Дацій, О. Свтух, В. Лагутін, І. Лютий, С. Кручко, П. Макаренко, М. Малік, М. Савлук, П. Саблук та багато інших. Відзначаючи вагомий внесок цих науковців у розвиток теорії і практики земельно-іпотечного кредитування, слід зауважити про об'єктивну необхідність розроблення ефективного механізму державного регулювання та підтримки використання ресурсного потенціалу іпотечного кредитування в аграрній сфері. 
Метою дослідження є аналіз стану державної фінансової підтримки аграрної сфери та виокремлення напрямів удосконалення державного регулювання фінансового забезпечення галузі через використання ресурсного потенціалу іпотечного кредитування.

Виклад основного матеріалу дослідження. Спрямування вектору державної політики в бік розвитку здорових конкурентних умов на ринку іпотечного кредитування сільськогосподарських виробників під заставу нерухомості, в тому числі земельно-іпотечного кредитування, $є$ одним із найважливіших факторів розширення спектру інвестиційної діяльності в аграрній сфері і запорукою стабільного розвитку галузі.

Загалом до основних напрямів діяльності держави у сфері комплексного всебічного розвитку аграрної галузі України належать:

- формування і підтримання в актуальному стані законодавчої бази - фундаменту державного регулювання;

- здійснення політики фінансової підтримки суб'єктів агарного підприємництва (зокрема, одним із найефективніших заходів підтримки та регулювання стану аграрної сфери з боку держави є кредитування);

- застосування інструментів та методів загального та спеціального регулювання (політика гнучкого регулювання залежно від етапу життєвого циклу галузі та економіки загалом, правила використання адміністративних методів державної політики регулювання);

- реалізація методів державного нагляду за діяльністю кредиторів та емітентів іпотечних цінних паперів;

- забезпечення формування й успішного функціонування інфраструктури іпотечного кредитування аграріїв, регламентація діяльності фінансових посередників [1, с. 20-21].

Натепер правові засади функціонування іпотечного кредитування в Україні визначено Законом України «Про іпотеку», Законом України «Про заставу», Земельним кодексом України, Законом України «Про іпотечне кредитування, операції з консолідованим іпотечним боргом та іпотечні сертифікати», Законом України «Про оцінку земель», Гос- подарським кодексом України, Законом України «Про державну реєстрацію речових прав на нерухоме майно та їх обмежень», Законом України «Про оцінку майна, майнових прав та професійну оціночну діяльність в Україні», Цивільним кодексом України, Законом України «Про охорону земель», Законом України «Про цінні папери і фондовий ринок» тощо. Причому, як зазначає Ю.Л. Мохова, Закон України «Про іпотеку» вважається одним із найпрогресивніших у Центральній та Східній Європі, оскільки зорієнтований на захист інтересів кредиторів і системно регулює іпотечні відносини [2, с. 88].

Оцінка стану фінансової підтримки розвитку аграрного сектору 3 боку держави може бути дана на основі аналізу обсягів фінансування $з$ Державного бюджету України програм підтримки суб'єктів аграрного підприємництва. Ці програми варто розглядати залежно від того, на якій основі вони здійснюються: поворотній чи безповоротній.

Обсяги та структурні співвідношення у державному фінансуванні видатків на певний період ілюструють основні напрями аграрної політики уряду, пріоритетні завдання та стратегічні цілі розвитку держави. Під час здійснення оцінки бюджетування аграрної сфери перше, на що варто звернути увагу, - це різке зростання планових обсягів фінансування на безповоротній основі у 2017 році порівняно 3 попередніми, що спричинило суттєві структурні зміни у фінансуванні державних програм підтримки аграріїв. Така динаміка була спричинена здебільшого за рахунок впровадження нової програми «Фінансова підтримка сільгосптоваровиробників», на яку в бюджеті 2017 року було закладено 4,8 млрд. грн. із сукупного обсягу підтримки аграріїв на безповоротній основі 5,4 млрд. грн. (табл 1).

Загалом збільшення обсягів бюджетного фінансування програм розвитку АПК у 2017 році можна пояснити тим, що Державний бюджет на цей рік складався 3 урахуванням скасування спеціального режиму оподаткування ПДВ сільськогосподарських товаровиробників, враховуючи вимоги МВФ [22, с. 51]. Зміна структури 
Види державних програм підтримки підприсмств АПК у 2017 році [3]

\begin{tabular}{|c|c|c|c|}
\hline Код програми & Програми підтримки підприємств АПК & $\begin{array}{l}\text { млн. } \\
\text { грн. }\end{array}$ & у \% до ВСГП \\
\hline \multicolumn{4}{|c|}{ Підтримка на безповоротній основі } \\
\hline 2801030 & $\begin{array}{l}\text { Фінансова підтримка заходів в агропромисловому комплексі } \\
\text { шляхом здешевлення кредитів }\end{array}$ & 300,0 & 0,042 \\
\hline 2801180 & Фінансова підтримка заходів в агропромисловому комплексі & 60,0 & 0,008 \\
\hline 2801350 & $\begin{array}{l}\text { Державна підтримка розвитку хмелярства, закладення мо- } \\
\text { лодих садів, виноградників та ягідників і догляд за ними }\end{array}$ & 75,0 & 0,011 \\
\hline 2801540 & Державна підтримка тваринництва & 170,0 & 0,024 \\
\hline 2801580 & Фінансова підтримка сільгосптоваровиробників & 4774,3 & 0,675 \\
\hline & Усього & 5379,3 & 0,760 \\
\hline \multicolumn{4}{|c|}{ Підтримка на поворотній основі } \\
\hline 2801460 & Надання кредитів фермерським господарствам & 65,0 & 0,009 \\
\hline 2801490 & $\begin{array}{l}\text { Фінансова підтримка заходів в агропромисловому комплексі } \\
\text { на умовах фінансового лізингу }\end{array}$ & 3,8 & 0,001 \\
\hline \multirow{2}{*}{\multicolumn{2}{|c|}{$\begin{array}{c}\text { Усього } \\
\text { ськогосподарської прод }\end{array}$}} & 68,8 & 0,010 \\
\hline & & 707792,0 & $X$ \\
\hline
\end{tabular}

фінансування державних програм підтримки АПК на безповоротній основі у 20132017 роках наведена на рис. 1. Важливим показником також $\epsilon$ зростання обсягів надання кредитів фермерським господарствам на поворотній основі через Український державний фонд підтримки фермерських господарств - у 2017 році порівняно з 2013 роком він зріс у 2,3 разу, при цьому загалом за на- прямом структура державної підтримки на поворотній основі відчула незначні коливання (рис. 2), які не мали суттєвого впливу на загальну картину

На фоні політичних змін, нестабільності зовнішньоекономічної ситуації та внутрішньодержавного соціально-економічного становища, що характеризують досліджуваний період в Україні, доцільно здійснити аналіз

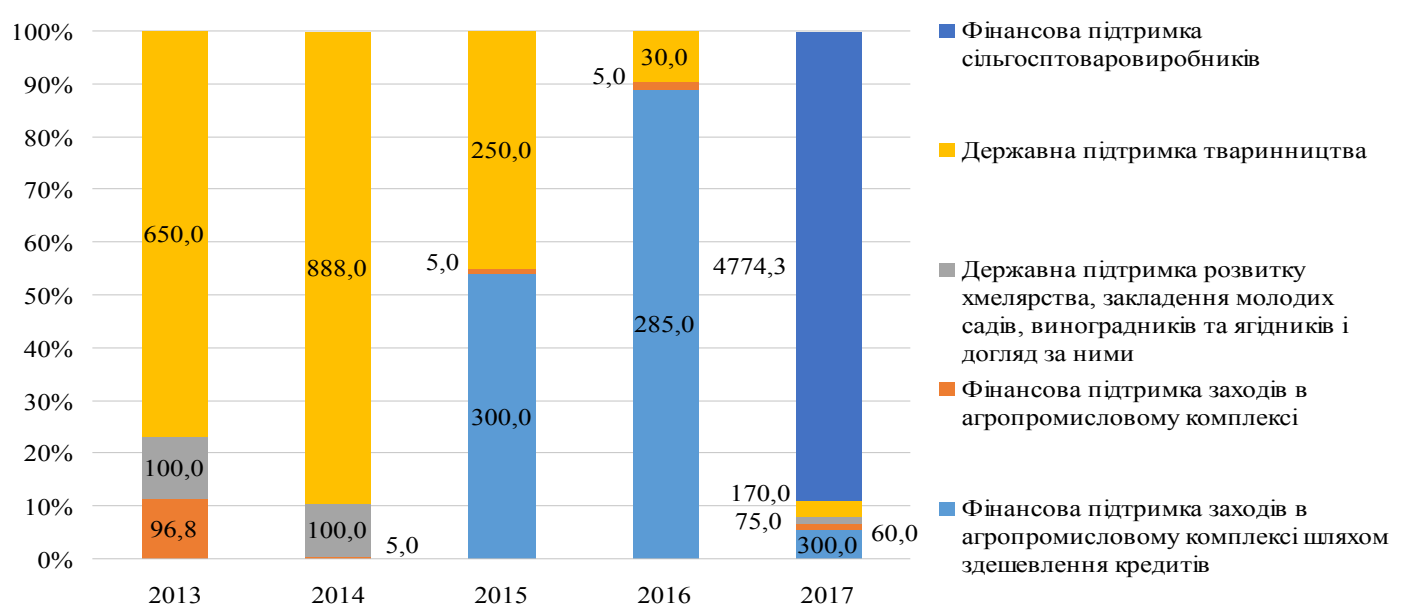

Рис. 1. Динаміка обсягів та структура фінансування державних програм підтримки АПК України на безповоротній основі у 2013-2017 роках, млн. грн

Складено автором за даними Державної казначейської служби України [3] 


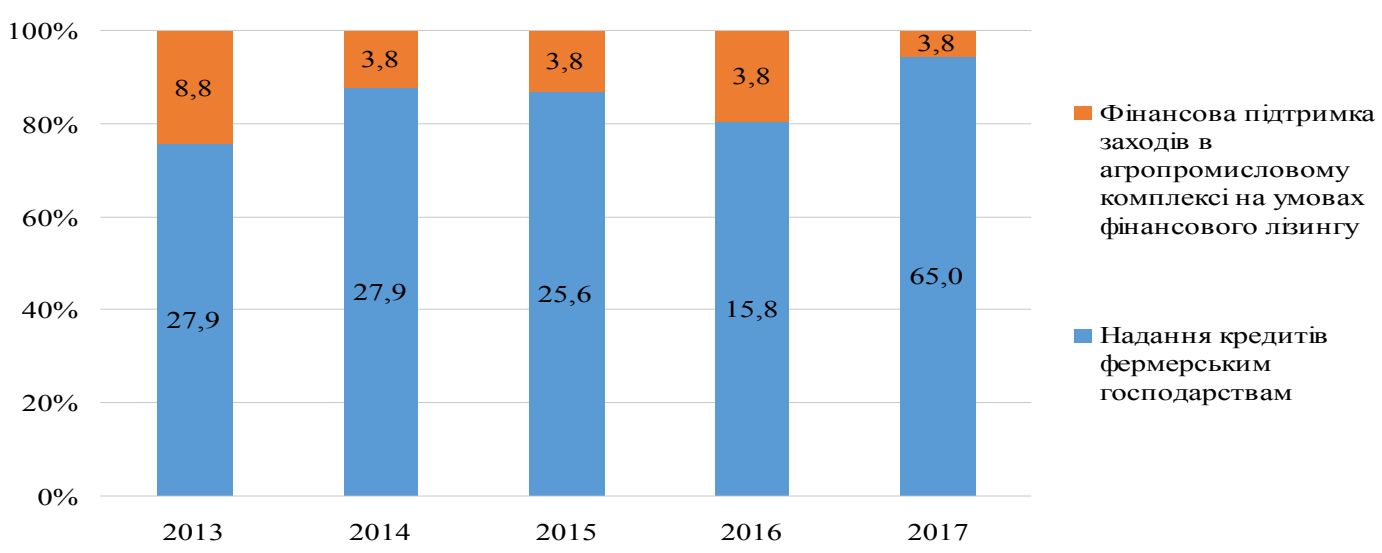

Рис. 2. Динаміка обсягів та структури фінансування державних програм підтримки АПК України на поворотній основі у 2013-2017 роках, млн. грн.

Складено автором за даними Державної казначейської служби України [3]

рівня виконання бюджетного фінансування програм розвитку АПК за 2013-2017 роки.

На рис. 3. графічно наведений рівень освоєння бюджетних коштів, спрямованих на реалізацію державних програм підтримки та розвитку аграрної сфери України у 2013-2017 роках.
Очевидно, що план з освоєння видатків Мінагрополітики до 2015 року не виконувався, і лише у 2015-2017 роках рівень його виконання лежав у межах 95,7-103,6\%. Менш оптимістичною $є$ картина щодо фінансування власне державних програм розвитку АПК,

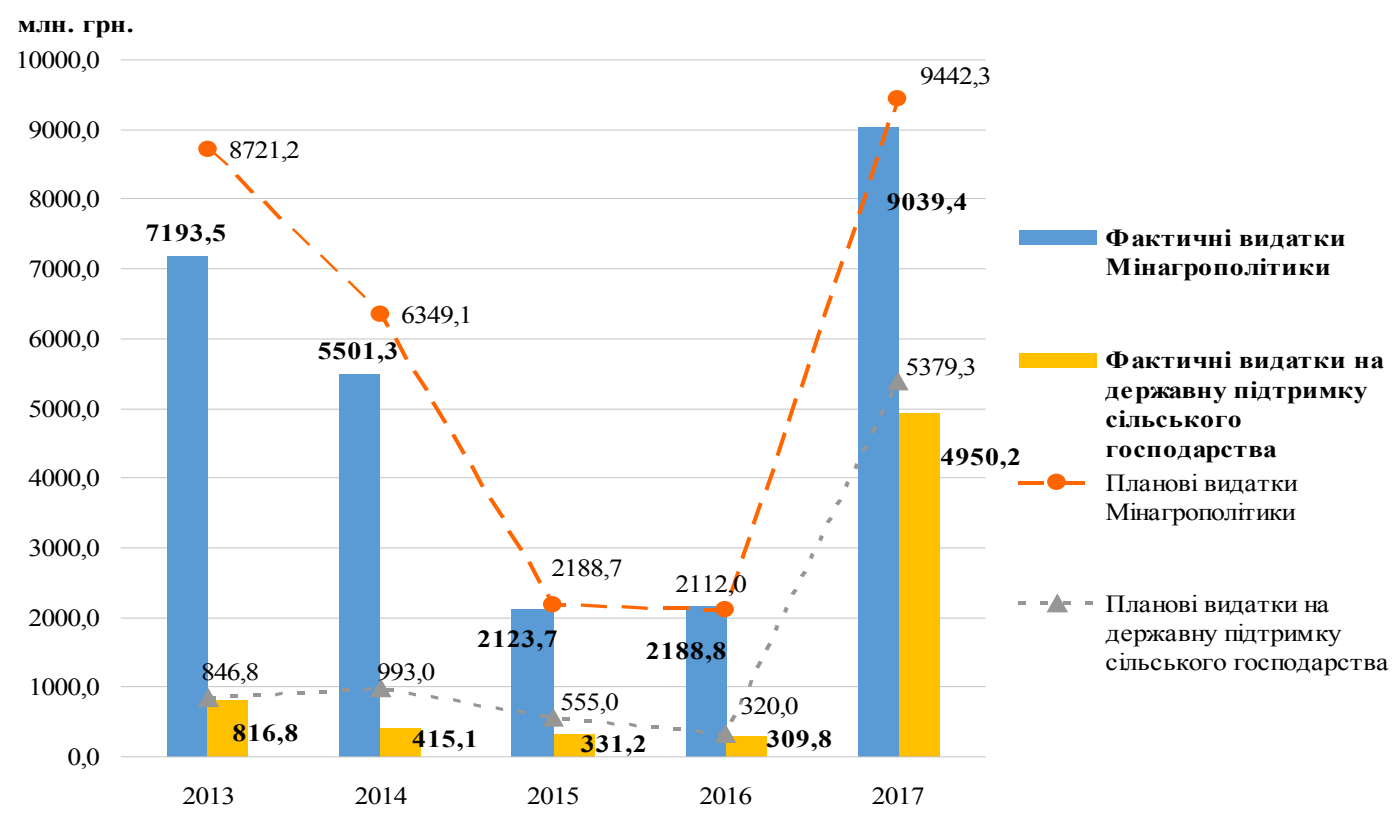

Рис. 3. Виконання планових показників фінансування програм розвитку АПК України у 2013-2017 роках

Складено автором за даними Держсавної казначейської служби Украӥни [3] 
оскільки у 2014-2015 роках було освоєно менше $60 \%$ виділених у державному бюджеті коштів. Така негативна тенденція була спричинена здебільшого відволіканням бюджетних коштів на військові видатки, а також нераціональним їх розподілом за напрямами.

Серед причин недовикористання бюджетних коштів можна також виділити:

- складність проходження та бюрократичність процедур отримання державної допомоги;

- недостатнє публічне висвітлення інформації щодо порядку реалізації державних програм підтримки аграріїв;

- втрату актуальності низки нормативно-правових актів та затягнутий законодавчий процес щодо оновлення цього порядку відповідно до чинного на той час бюджетного процесу;

- значна частка запланованих видатків фінансується із Спеціального фонду, що знижує гарантії фактичного їх спрямування за напрямами.

Проте вже у 2016 та 2017 роках спостерігалося практично вичерпне освоєння запланованих видатків за статтями:

- «Фінансова підтримка заходів в агропромисловому комплексі шляхом здешевлення кредитів» $-98,3 \%$;

- «Державна підтримка галузі тваринництва» - $100 \%$ і $98 \%$ відповідно у 2016 і 2017 роках;

- «Фінансова підтримка сільгосптоваровиробників» - 88\% у 2017 році.

Програма державної підтримки розвитку хмелярства, закладення молодих садів, виноградників та ягідників і нагляду за ними у 2017 році була профінансована у 4-кратному розмірі порівняно із запланованим рівнем.

Величина витрат, що припадає на 1 га сільськогосподарських земель, протягом досліджуваного періоду постійно змінювалася: спочатку зменшуючись (протягом 20132015 років), досягнувши у 2015 році свого мінімуму - 48 грн. на 1 га земель, а після змін у законодавстві стосовно скасування спецрежиму оподаткування цей показник зазнав різкого зростання - до 211,6 грн. на 1 га земель сільськогосподарського призначення у 2017 році.

Показники відношення видатків Мінагрополітики та прямих витрат на підтримку АПК до обсягу валової продукції сільського господарства також мали подібну тенденцію - з 2013 до 2016 року відсоток бюджетного фінансування в 1 грн. реалізованої продукції аграрного товаровиробництва постійно зменшувався, досягнувши мінімальної точки у 2016 році $(0,34 \%$ - видатки Мінагрополітики, 0,05\% - прямі видатки на підтримку АПК). Проте вже у 2017 році частка прямих видатків на підтримку аграрної сфери у вартості випущеної продукції сільського господарства досягла $0,7 \%$, майже втричі перевищивши рівень асигнувань 2013 року. Загалом рівень державної підтримки аграрної сфери за аналізований період можна оцінити як незадовільний, враховуючи те, що відповідно до вимог СОТ та ЄС мінімальний розмір державної підтримки аграрної галузі повинен становити 5\% від вартості продукції сільськогосподарського виробництва для розвинених країн та $10 \%$ для країн, що розвиваються [4, с. 25].

На нашу думку, встановлена законодавством України пріоритетність надання земель сільськогосподарського призначення громадянам України, державним та комунальним сільськогосподарським підприємствам, установам та організаціям для сільськогосподарських потреб $\epsilon$, безумовно, важливим фактором захисту цінних родючих грунтів та угідь від соціально-економічно та екологічно небезпечного перерозподілу національного багатства на користь іноземних промислових корпорацій. Подібна політика держави є цілком зрозумілою і логічною з огляду на цінність наявної можливості та значного потенціалу України забезпечувати продовольчу безпеку не лише власну, а й країн чи не всіх континентів світу.

Проте наявні в нашій державі умови функціонування аграрних товаровиробників та інших суб'єктів аграрної промисловості не забезпечують належним чином можливостей достатнього фінансування господарської діяльності в цій галузі. Часом занадто складні процедури залучення капіталу в аграрну 
сферу породжують деструктивні явища у сільському господарстві, коли максимальне виснаження природних ресурсів вбачається орендарями сільськогосподарських угідь чи не єдиним шляхом нарощування обсягів виробництва й отримання прибутків у короткостроковій перспективі; коли дрібні і середні аграрні підприємства не мають змоги здійснити принаймні часткове технічне переоснащення, «потопаючи» у зобов'язаннях перед бюджетом та кредиторами; коли наукові розробки і досягнення в аграрній сфері стають недосяжними для впровадження їх на практиці за браком фінансових ресурсів на реалізацію інноваційних проектів тощо.

Нестабільність політичної ситуації в країні, незавершена земельна реформа та потреба аграрної промисловості у значних капіталовкладеннях породжують скептичні настрої серед фермерських господарств щодо спроможності держави забезпечити необхідні умови для покращення інвестиційного клімату галузі. Водночас кредитно-фінансові установи, які здійснюють функції іпотечних кредитодавців у зв'язку з високою ризиковістю сільськогосподарської діяльності, намагаються уникати довгострокового іпотечного кредитування, надаючи перевагу менш ризиковим коротко- і середньостроковим кредитам під заставу нерухомості з високою ставкою дохідності [5, с. 1165].

Натепер фактичною перепоною для повноцінного функціонування земельно-іпотечного кредитування аграрної промисловості $€$ наявна в державі заборона відчуження земельних ділянок сільськогосподарського призначення. Де-юре є можливість застави земель із метою залучення грошових ресурсів на фінансування господарської діяльності та отримання в кінцевому результаті доходів, 3 яких буде погашена іпотечна позика, проте де-факто іпотекодержатель, а це, як правило, комерційний банк, у разі неспроможності позичальника погасити кредит буде вимушений реалізовувати заставлене майно, що у разі із земельними ділянками сільськогосподарського призначення $\epsilon$ неможливим відповідно до норм Земельного кодексу України. Таким чином, потенційно потужний канал руху фінансових ресурсів за рахунок земельно-іпотечного кредитування суб'єктів аграрного підприємництва ниніі залишається зачиненим.

Висновки 3 проведеного дослідження. У результаті проведеного аналізу стану державного забезпечення аграрної сфери у 20132017 роках можемо свідчити про наявність значної потреби суб'єктів аграрного підприємництва у бюджетній підтримці галузі шляхом реалізації заходів прямого та непрямого державного регулювання. Слід констатувати, що, на нашу думку, в Україні складається сприятлива макроекономічна ситуація для розвитку іпотечного кредитування. Так, завершена стабілізація банківського сектору, банківські установи мають надмірну ліквідність, знижується облікова ставка. Зниження відсоткових ставок за депозитними внесками приводить до того, що власники депозитів змушені шукати нові інструменти збереження коштів, якими можуть виступати іпотечні облігації та іпотечні сертифікати.

Реформаційні зрушення, пов'язані $з$ інтеграцією до ЄC та COT, а також вимогами МВФ, несуть у собі конструктивні зміни, що в кінцевому підсумку мають на меті становлення в Україні повноцінної, стабільної та ефективної системи агроінвестування, в тому числі за рахунок розвитку інфраструктури іпотечного кредитування суб'єктів аграрного бізнесу та зростання доступності кредитних ресурсів для тих із них, що не належать до агрохолдингів та корпорацій.

Не менш важливими $є$ й організаційні методи державного регулювання і підтримки використання ресурсного потенціалу іпотечного кредитування в аграрній сфері, що повинні передбачати:

- систему спеціалізованих іпотечних кредитних інститутів, включаючи державну іпотечну установу;

- систему державної реєстрації прав на нерухоме майно та іпотеки, державний земельний кадастр;

- систему нотаріальних послуг; оціночної, страхової, судової діяльності; фондовий ринок та ринки цінних паперів; бюро кредитних історій тощо. 


\section{Список літератури:}

1. Прокопенко В.Ю. Регулююча роль держави в розвитку іпотечного кредитування землі. Проблеми економіки. 2010. № 3. С. 19-22.

2. Мохова Ю.Л. Сутність та складові механізму державного регулювання іпотечного кредитування в Україні. Держава та регіони. Серія: Державне управління. 2012. № 2 (38). С. 88-90.

3. Державна казначейська служба України [Офіційний веб-сайт]. - URL: http://www.treasury.gov.ua/main/uk/index (Дата звернення 28.03.2019).

4. Осташко Т.О. Сільське господарство в умовах СОТ і ЄС. Київ: Інститут сільського розвитку, 2005. $70 \mathrm{c.}$

5. Мельник Л.В. Державне регулювання та підтримка використання ресурсного потенціалу іпотечного кредитування в аграрній сфері. Економіка i суспільство. 2017. Випуск 13. С. 1165-1172.

\section{References:}

1. Prokopenko V.Yu.(2010) Rehuliuiucha rol derzhavy v rozvytku ipotechnoho kredytuvannia zemli [The regulatory role of the state in the development of land mortgage lending]. Problemy ekonomiky, № 3. pp. 19-22.

2. Mokhova Yu.L.(2012) Sutnist ta skladovi mekhanizmu derzhavnoho rehuliuvannia ipotechnoho kredytuvannia v Ukraini. [The essence and components of the mechanism of state regulation of mortgage lending in Ukraine]. Derzhava ta rehiony. Seriia: Derzhavne upravlinnia, № 2 (38). pp. 88-90.

3. Derzhavnakaznacheiska sluzhbaUkrainy[Ofitsiinyiveb-sait].-URL:http://www.treasury.gov.ua/ main/uk/index (accessed 28.03.2019)

4. Ostashko T.O. (2005) Silske hospodarstvo v umovakh SOT i YeS. [Agriculture in the WTO and the EU] Kyiv: Instytut silskoho rozvytku, 70 p. (in Ukrainian).

5. Melnyk L.V.(2017) Derzhavne rehuliuvannia ta pidtrymka vykorystannia resursnoho potentsialu ipotechnoho kredytuvannia $\mathrm{v}$ ahrarnii sferi [State regulation and support for utilization of the resource potential of mortgage lending in the agricultural sector]. Ekonomika i suspilstvo, Vypusk 13. pp. 1165-1172. 